\title{
Investigation of High-Precision Laser Instrument for Fabrication of Integrated Circuits and Monitoring of Seismic and Gravitational Processes
}

\author{
Iu.B. Minin ${ }^{1,2}$, D.V. Aleksandrov ${ }^{2}$, M.N. Dubrov ${ }^{2}$, M.V. Fedorov ${ }^{1}$ \\ ${ }^{1}$ Skolkovo Institute of Science and Technology, Skoltech Center for Computational Data-Intensive \\ Science and Engineering, Moscow, Russia, Iurii.Minin@ @skoltech.ru \\ ${ }^{2}$ Fryazino Branch of Kotel'nikov Institute of Radio-Engineering and Electronics of RAS, Fryazino, \\ Moscow Region, Russia
}

\begin{abstract}
A new method of interferometric strain measurements was proposed. The method possesses high interferometric precision, does not require moving external mirror through measuring base and is characterized by use of improved signal post-processing with utilizing linearization and digital processing techniques. The proposed method is investigated for achieving accuracy of decades of nanometers in a wide dynamic range up to 200 dB with a sensitivity of strain detection of the order of $10^{-12}$.
\end{abstract}

Keywords — interferometer, strainmeter, vibrometer.

\section{INTRODUCTION}

High-precision instruments are necessary in different areas, especially for applications in fabrication of microand nano- devices such as integrated circuits. Moreover, there are other applications [1, 2].

Seismic situation predicting is extremely important in such regions as Caucasus, Japan, Kamchatka, Malaysia, Philippines because it is necessary to save lives as much as possible.

In addition, there is a need in monitoring of gravitational waves for deepening of humanity knowledge in such disciplines as physics, astronomy, and astrophysics [3, 4, 5].

Nowadays, the different techniques can be applied for solving those problems. For instance, on one hand, radiooptical method of measuring distances utilizes counting number of periods of envelope of amplitude-modulated signal [6] and achieves accuracy of $0.1 \mathrm{~mm}$. On other hand, interference method consists in counting number of interference fringes while external mirror is being moved along entire measured distance [7]. For example, highly sensitive interferometers as deformometers are applicable for studying acoustic and seismic processes occurring in the environment [8].

The implementation of the methods includes the determination of feedback parameters and the installation of stabilization modes, as well as the development of methods for digital processing of interferometric data [9].
However, those instruments can require movements of external mirror possess accuracy of the order of $0.1 \mathrm{~mm}$ on distance of measurements of the order within $10^{-2}-10^{4} \mathrm{~m}$ [10].

There is still no apparatus that does not possess any of those disadvantages. Therefore, we propose the principle for measurements of distances and displacements by combining advantages of the methods.

In addition, one of distinctive feature of the proposed method consists in post-processing by using Fourieranalysis and linearization methods for reducing registration system noise level and for broadening dynamic range of signal registration.

Classical interference methods were modernized with optical feedback. In this case, frequency modulation of radiation based on electro-optical, acousto-optical and piezo effects is used [11]. The frequency modulation of the interference signal is also provided by superposition of two waves of different optical frequencies. One of the methods of frequency modulation, based on the well-known property of semiconductor lasers to change the radiation frequency under the influence of changes in the injection current [12], made it possible to determine the distance to the object when using sinusoidal frequency modulation [13] and conduct simultaneous measurements of the range and velocity of diffusely scattering objects with linear frequency modulation [14].

We propose to use an interferometer based on a threemirror laser resonator with a new phase-frequency modulation method based on the superposition of two independent modulation processes. One of them is carried out using an electro-optical modulator (EOM), the modulation frequency is set by a sawtooth reference voltage $(30 \mathrm{kHz})$ from an external source, this allows recording an interference signal even in the absence of deformation vibrations. The second modulation process is caused by changes in the length of the measuring arm of the interferometer in accordance with the deformation vibrations. In this case, the radiation parameters are controlled with a slow continuous adjustment of the cavity 
length of the laser during operation in accordance with changes in the measuring arm of the interferometer.

The feedback parameters are proposed to be determined by experimental modeling and by the characteristics of the electromagnetic field in a three-mirror laser resonator obtained from solving integral equations and numerical calculations. When developing digital processing techniques, Fourier transform methods are used and linearization methods are being developed, which makes it possible to compensate for interference introduced by the registration system and increase its dynamic range.

The aim of this work is to investigate a method of highprecision frequency-modulated laser interferometry based on frequency modulation of radiation from external mirrors which is applicable in studying spectral-time characteristics of acoustic and seismic vibrations in a wide dynamic and time ranges; implementation of the method and confirmation by experiments.

\section{RESULTS}

A. Visibility of interference pattern

Derived formulas

$$
V_{1}=\frac{2 \sqrt{\delta_{1}}}{1+\delta_{1}} ; \quad V(\ell, L)=V_{1} V_{2}(\ell, L) ;
$$

$$
V_{2}(\ell, L)=\frac{2 \sqrt{1+\delta_{2}^{2}+2 \delta_{2} \cos \left(\frac{4 \pi \Delta v(L)}{c} \ell\right)}}{1+\delta_{2}} ;
$$

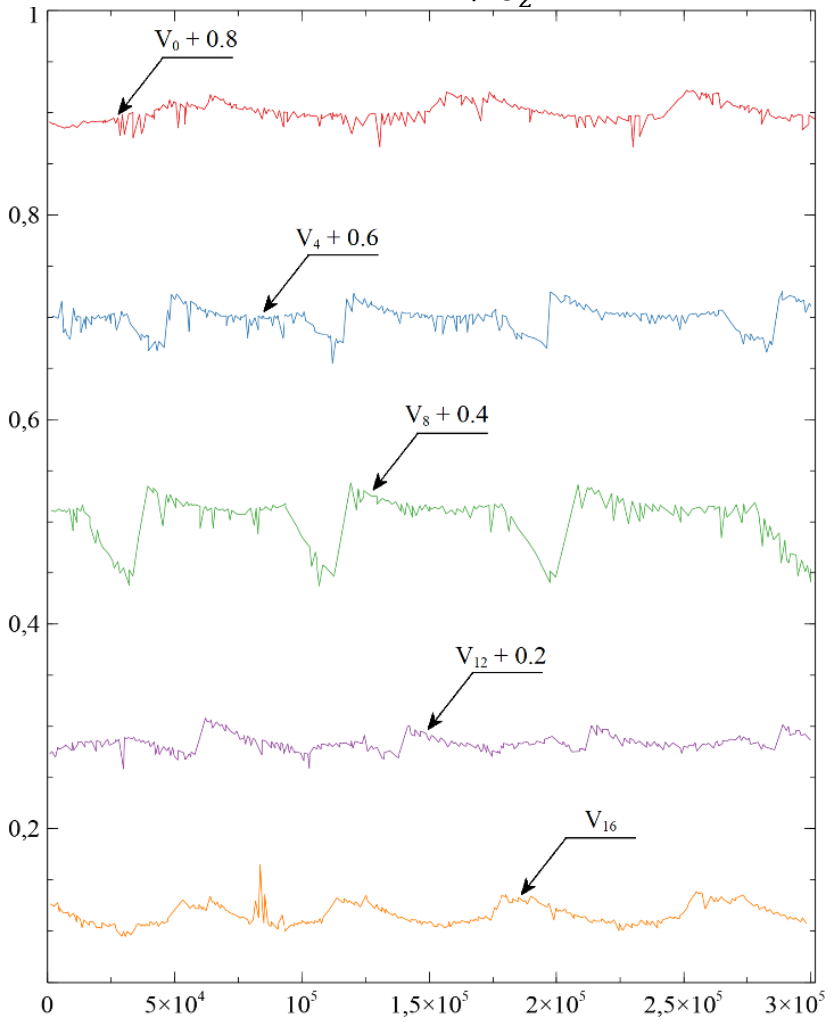

Fig. 1. Visibility versus time (milliseconds) describe the visibility of interference pattern of two-mode radiation.

The experiment for investigating dependence visibility versus time was carried out by using He-Ne laser of cavity length of $16 \mathrm{~cm}$. The laser and an external mirror constitute a three-mirror interferometer. The visibility curves $\mathrm{V}_{0}, \mathrm{~V}_{4}$ $\mathrm{V}_{8}, \mathrm{~V}_{12}, \mathrm{~V}_{16}$ (offset by $0.8,0.6,0.4,0.2$ and 0 , respectively) are shown (Fig. 1) at the positions of the reflecting object at distances from the laser $\ell$ of $0 \mathrm{~cm}, 4 \mathrm{~cm}, 8 \mathrm{~cm}, 12 \mathrm{~cm}, 16$ $\mathrm{cm}$, respectively. These curves describe the periodic change in the visibility values over time due to changes in the length of the laser resonator L during self-heating of the laser. The most abrupt changes in gradient were obtained on the $\mathrm{V}_{8}$ visibility curve near the minima $(\approx 35 \mathrm{~s}, \approx 110 \mathrm{~s}, \approx 200 \mathrm{~s}$, $\approx 300 \mathrm{~s}$ ) (two-mode laser mode). In addition, on each visibility curve, there is a periodicity of the section where the visibility gradient almost does not change. For example, on the visibility curve $\mathrm{V}_{8}$, insignificant (compared to the areas in the vicinity of the minima) changes in visibility are observed in such areas as 45-100 s, 125-180 s, 212-280 s (single-mode laser mode)

\section{B. Linearization}
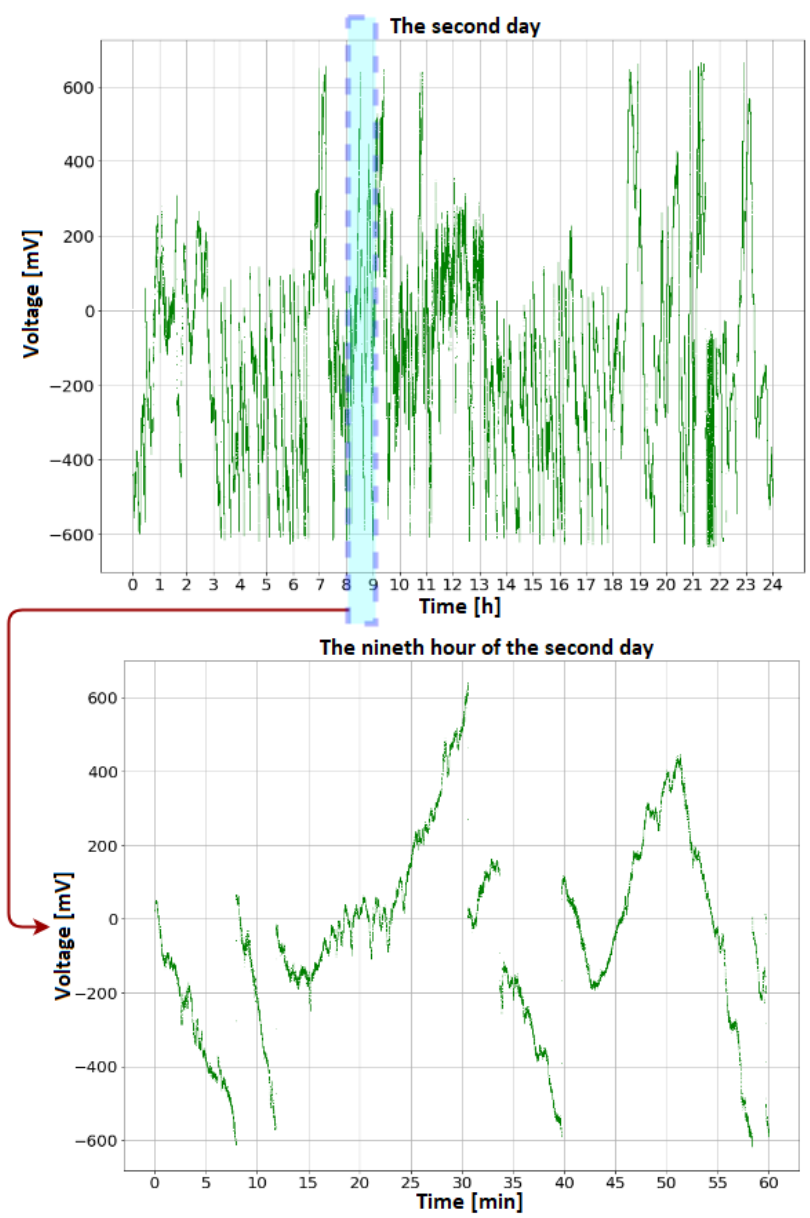

Fig. 2. Visualization of source data of seismic vibrations during the second day of measurements (above) and its hour detailing (below)

Fig. 2 represents signal reference point offsetting made by voltage registration system. Registered signal is being 
got from photodetector which writes data about light interference in three-mirror scheme.

The interferometer registration device operates in the range of $\pm 8 \lambda / 2$ ( \pm 2.5 microns), while each vertical offset of the reference point of the registration system corresponds to an offset of 2.5 microns.

Those offsets can be eliminated as part of signal postprocessing. In addition, linearization was applied for decreasing side signals and increasing deformation signals.

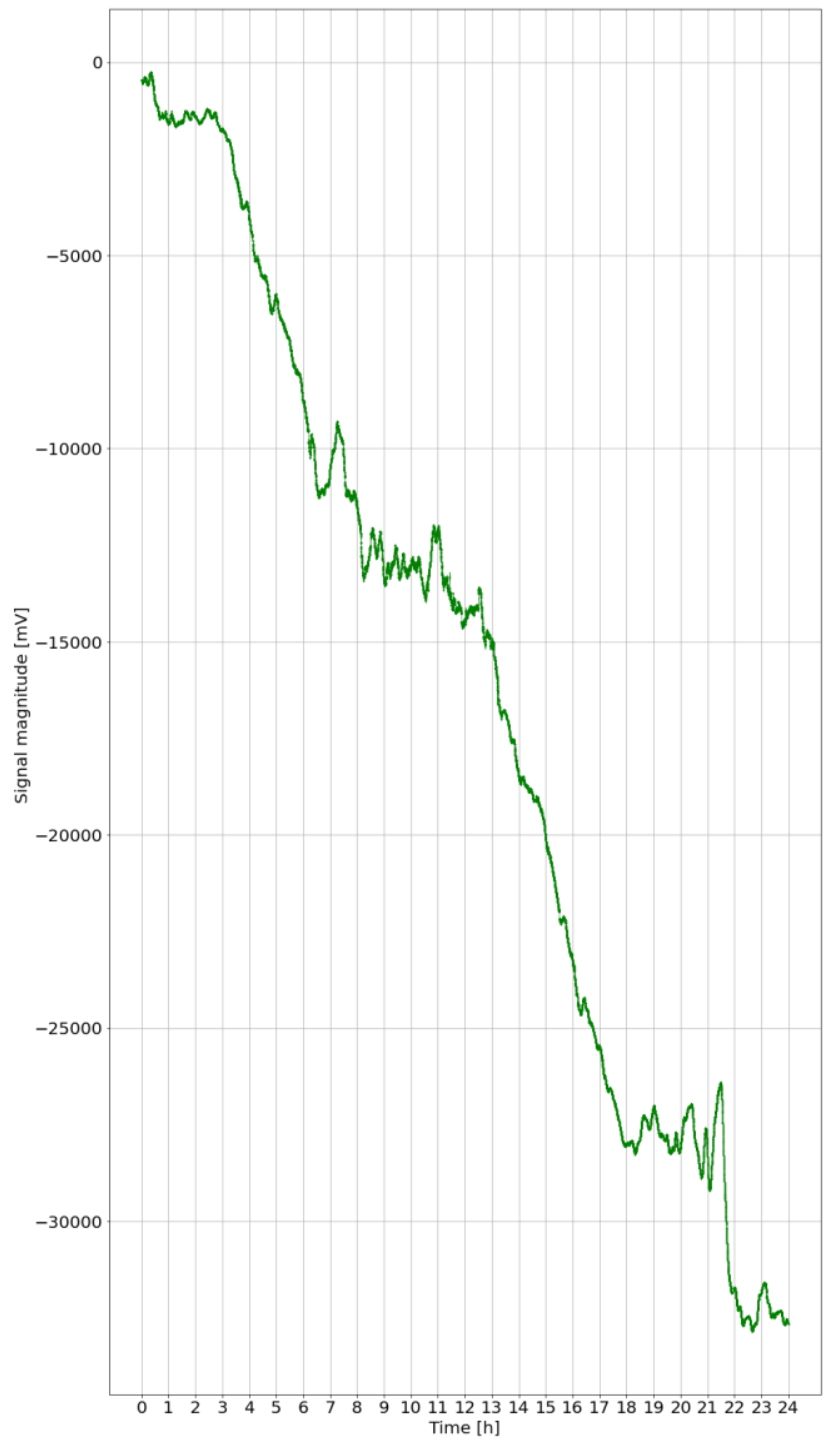

Fig. 3. Linearized data of seismic vibrations during the third day of measurements

Fig. 3 demonstrates linearized data of seismic vibrations during the third day.

The spectral-time diagram (Fig. 4) shows the amplitudefrequency changes in the nature of the signal over time in the frequency range $0-5000 \mathrm{mHz}(0-5 \mathrm{~Hz})$ during the last two hours of the fourth day of the data obtained. In Fig. 4, a seismic process is highlighted in green, expressed by a linear spectrum in the form of wide band of frequency of $\approx 1800$ $\mathrm{mHz}$. The frequency deviation width is changing with time between $\approx 100 \mathrm{mHz}$ and $\approx 500 \mathrm{mHz}$. This means that this process is a frequency-modulated quasi-harmonic pulse. This may be due to an anthropogenic source of seismic vibration [15]. In the frequency ranges between $800 \mathrm{mHz}$ and $1100 \mathrm{mHz}$ and from $3000 \mathrm{mHz}$ to $4000 \mathrm{mHz}$, the amplitude of the recorded processes drops to the background level of 40 to $60 \mathrm{~dB}$, which is noted in lightgreen/white. This makes it possible to register P-waves with a high signal-to-noise ratio, since their energy is mainly concentrated in this frequency range [15].

Spectrum of difference of source signal and its linearization is represented in the Fig. 5.

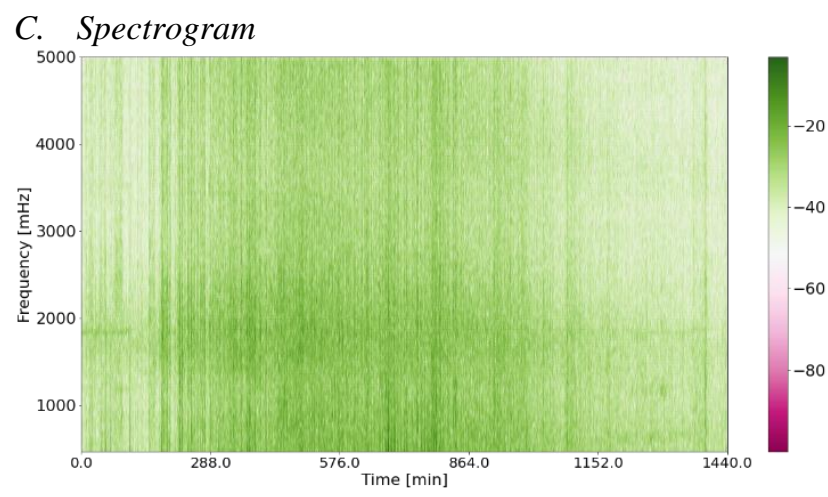

Fig. 4. Spectrogram of the second day of measurements

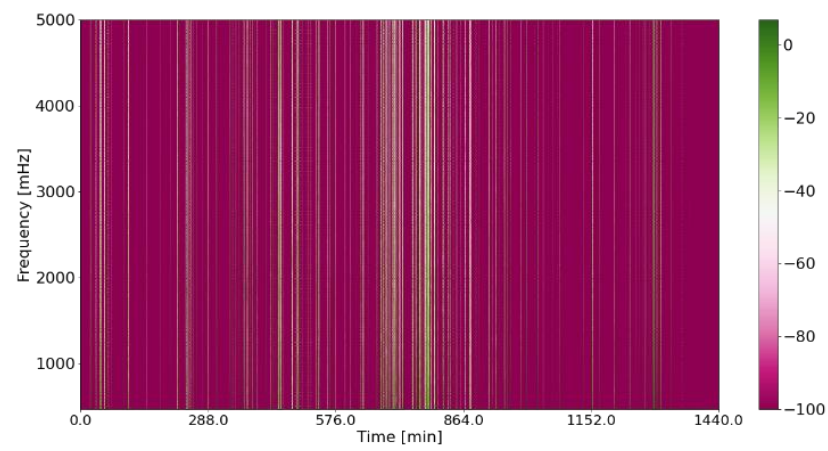

Fig. 5. Spectrogram of the difference

\section{CONCLUSION AND DISCUSSION}

The achieved minimums in visibility graphs are considerably sharper in comparison with maximums. Maximums are relatively gentle. Thus, minimum visibility detection may give greater sensitivity for device. However, usually noises deteriorate more valuably for maximums than for minimums. That is possible topic for future studies.

Signal reference point offsetting and linearizing techniques increase SNR (signal to noise ratio) and allow studying the spectral-temporal characteristics of acoustic and seismic vibrations in a wide dynamic and time ranges. That has been confirmed by computational and physical experiments where density of frequency-independent nonzero parts represented as spectrum of difference of source signal and its linearization is negligible in comparison with spectrum of the linearized signal. 


\section{ACKNOWLEDGEMENT}

The work was carried out within the framework of the state task 0030-2019-0014.

We would like to thank I.S. Bulatov and N.A. Korobov for their wonderful collaboration.

\section{REFERENCES}

[1] Rabaey J. M., Chandrakasan A. P., Nikoli'c B. Digital integrated circuits: a design perspective. - Pearson education Upper Saddle River, NJ, 2003. — Vol. 7.

[2] Grebene A. B. Bipolar and MOS analog integrated circuit design. - John Wiley \& Sons, 2002.

[3] Barish B. C., Weiss R. Ligo and the detection of gravitational waves // Physics Today. - 1999. - Vol. 52. - P. 44-50.

[4] Spacecraft high precision optimized control for free-falling test mass tracking in LISA-pathfinder mission / D. Bortoluzzi, M. Da Lio, R. Oboe, S. Vitale // The 8th IEEE International Workshop on Advanced Motion Control, 2004. AMC '04. - 2004. - March. - P. 553-558.

[5] Harry G. M., Collaboration L. S. et al. Advanced ligo: the next generation of gravitational wave detectors // Classical and Quantum Gravity. — 2010. — Vol. 27, no. 8. - P. 084006.

[6] Garc'ia R. Amplitude modulation atomic force microscopy. — John Wiley \& Sons, 2011

[7] Saulson P. R. Fundamentals of interferometric gravitational wave detectors. - World Scientific, 1994

[8] Knuuttila J. V., Tikka P. T., Salomaa M. M. Scanning michelson interferometer for imaging surface acoustic wave fields // Optics letters. — 2000. — Vol. 25, no. 9. - P. 613615.
[9] Continuous phase stabilization and active interferometer control using two modes / Gregor Jotzu, Tim J Bartley, Hendrik B Coldenstrodt-Ronge et al. // Journal of Modern Optics. - 2012. - Vol. 59, no. 1. - P. 42-45.

[10] Iu.B.Minin, M.N.Dubrov, V.M.Shevchenko. Method and device for precision laser interference measurement of distances and displacements. - RF Patent N 2721667, May 21, 2020. - Access mode: https://www1.fips.ru/registersdoc-view/fips_servlet?DB=

RUPAT\&DocNumber=2721667\&TypeFile $=\mathrm{html}$.

[11] Visualization of an acoustic stationary wave by optical feedback interferometry / Patricio Fernando Urgiles Ortiz, Julien Perchoux, Antonio Luna Arriaga et al. // Optical Engineering. - 2018. - Vol. 57, no. 5. - P. 051502.1

[12] Alexandrov D., Remontov M. Issledovanie stabilizirovannykh lazerov $\mathrm{s}$ avtopodstroykoy chastoty (investigation of stabilized lasers with frequency autoadjustment) // Nelineyny Mir. - 2007. - Vol. 5, no. 5. P. 299-300.

[13] Aleksandrov D. Razrabotka metodov issledovaniya svojstv nanomaterialov $\mathrm{s}$ ispol'zovaniem lazernyh interferometrov $\mathrm{i}$ komp'yuternoj obrabotki dannyh (development of methods for studying the properties of nanomaterials using laser interferometers and digital data processing) // Perspektivnye materialy. - 2010. - no. 9. - P. 9-11.

[14] Aleksandrov D., Dubrov M., Shatrov A. Osobennosti raboty vysokostabil'nyh lazerov pri podklyuchenii nesoglasovanno opticheskoj nagruzki (Features of the operation of highly stable lasers when connecting an inconsistent optical load) // Radiotekhnika i elektronika. — 2011. — Vol. 56, no. 9. P. 1149-1149.

[15] Chapman C. Fundamentals of seismic wave propagation. Cambridge university press, 2004.

\title{
Изучение высокоточного лазерного прибора для исследования интегральных схем и мониторинга сейсмических и гравитационных процессов
}

\author{
Ю.Б. Минин ${ }^{1,2}$, Д.В. Александров ${ }^{2}$, М.Н. Дубров ${ }^{2}$, М.В. Федоров ${ }^{1}$ \\ ${ }^{1}$ Сколковский институт науки и технологий, Центр по научным и инженерным \\ вычислительным технологиям для задач с большими массивами данных, Москва, Россия, \\ Iurii.Minin@skoltech.ru \\ ${ }^{2}$ Фрязинский филиал Института радиотехники и электроники им. В.А. Котельникова РАН, \\ Фрязино, Московская область, Россия
}

\begin{abstract}
Аннотация - Предложен новый метод интерферометрических измерений деформаций. Способ сочетает в себе интерферометрическую точность, не требует перемещения внешнего зеркала через измерительную базу и характеризуется использованием улучшенной постобработки сигнала за счет использования методов линеаризации и цифровой
\end{abstract}

обработки. Предлагаемый способ исследуется для достижения точности в десятки нанометров в широком динамическом диапазоне до 200 дБ с чувствительностью обнаружения деформации порядка $10^{-12}$.

Ключевые слова - интерферометр, стрейнметр, виброметр. 


\section{ЛИТЕРАТУРА}

[1] Rabaey J. M., Chandrakasan A. P., Nikoli'c B. Digital integrated circuits: a design perspective. - Pearson education Upper Saddle River, NJ, 2003. - Vol. 7.

[2] Grebene A. B. Bipolar and MOS analog integrated circuit design. - John Wiley \& Sons, 2002.

[3] Barish B. C., Weiss R. Ligo and the detection of gravitational waves // Physics Today. - 1999. - Vol. 52. - P. 44-50.

[4] Spacecraft high precision optimized control for free-falling test mass tracking in LISA-pathfinder mission / D. Bortoluzzi, M. Da Lio, R. Oboe, S. Vitale // The 8th IEEE International Workshop on Advanced Motion Control, 2004. AMC '04. - 2004. - March. - P. 553-558.

[5] Harry G. M., Collaboration L. S. et al. Advanced ligo: the next generation of gravitational wave detectors // Classical and Quantum Gravity. - 2010. - Vol. 27, no. 8. - P. 084006.

[6] Garc'1a R. Amplitude modulation atomic force microscopy. — John Wiley \& Sons, 2011.

[7] Saulson P. R. Fundamentals of interferometric gravitational wave detectors. - World Scientific, 1994.

[8] Knuuttila J. V., Tikka P. T., Salomaa M. M. Scanning michelson interferometer for imaging surface acoustic wave fields // Optics letters. - 2000. — Vol. 25, no. 9. - P. 613615.

[9] Continuous phase stabilization and active interferometer control using two modes / Gregor Jotzu, Tim J Bartley,
Hendrik B Coldenstrodt-Ronge et al. // Journal of Modern Optics. - 2012. - Vol. 59, no. 1. - P. 42-45.

[10] Ю.Б.Минин, М.Н.Дубров, В.М. Шевченко. Способ и устройство для прецизионного лазерноинтерференционного измерения расстояний и перемещений. - Патент РФ № 2721667, 21 мая, 2020. Онлайн-доступ: https://www1.fips.ru/registers-docview/fips_servlet?DB $=$ RUPAT\&DocNumber=2721667\& $\mathrm{TypeFile=html}$.

[11] Visualization of an acoustic stationary wave by optical feedback interferometry / Patricio Fernando Urgiles Ortiz, Julien Perchoux, Antonio Luna Arriaga et al. // Optical Engineering. - 2018. - Vol. 57, no. 5. - P. 051502.

[12] Александров Д., Ремонтов М. Исследование стабилизированных лазеров с автоподстройкой частоты // Нелинейный мир. - 2007. - Том 5, № 5. - С. 299 300.

[13] Александров Д.В. Разработка методов исследования свойств наноматериалов с использованием лазерных интерферометров и компьютерной обработки данных // Перспективные материалы. - 2010. - № 9. - С. 9-11.

[14] Александров Д., Дубров М., Шатров А. Особенности работы высокостабильных лазеров при подключении несогласованной оптической нагрузки //Радиотехника и электроника. - 2011. - Том 56, № 9. - С. 1149-1149.

[15] Chapman C. Fundamentals of seismic wave propagation. Cambridge university press, 2004. 